\title{
Plant and livestock waste compost compared with inorganic fertilizer: nutrient contribution to soil
}

\author{
Aporte nutricional al suelo mediante fertilizantes químicos y abonos orgánicos \\ de residuos vegetales y pecuarios
}

\author{
Ofelia Adriana Hernández Rodríguez¹, César H. Rivera Figueroa ${ }^{1 *}$, Elías E. Díaz Ávila², \\ Dámaris L. Ojeda Barrios ${ }^{1}$, and Víctor M. Guerrero Prieto ${ }^{1}$
}

\footnotetext{
${ }^{1}$ Facultad de Ciencias Agrotecnológicas, ${ }^{2}$ Graduado de la Facultad de Ciencias Agrotecnológicas. Universidad Autónoma de Chihuahua, Ciudad Universitaria S/N. 31310 Chihuahua, Chihuahua, México.

* Autor responsable (crivera@uach.mx)
}

\section{SUMMARY}

The use of livestock and plant wastes, as sources of nutrients and organic material to the soil, is a viable alternative to chemical fertilizers, which eventually cause serious risks to agroecosystems. The present study was conducted in 2013 in a greenhouse at FACIATECUACH, Chihuahua, México. Four composts made with (a) cow manure, (b) hen manure, (c) sawdust and (d) maize stover were evaluated for their contribution of the soil macronutrients $\mathrm{NO}_{3}^{-}, \mathrm{P}^{=}, \mathrm{K}^{+}, \mathrm{Ca}^{++}, \mathrm{Mg}^{++}$and $\mathrm{Na}^{+}$and compared with urea as a synthetic fertilizer and a control without fertilizer. The experiment was based on a completely randomized design; statistical analysis included an analysis of variance using the statistical package SAS (Statistical Analysis System) version 9.3.1 and comparison of means with the Tukey procedure $(a=0.05)$. Results suggest that five of the compost treatments increased the concentration of $\mathrm{NO}_{3}^{-}$. Hen manure significantly outperformed cow manure in providing $\mathrm{NO}_{3}^{-}$and $\mathrm{P}^{-}$. Likewise, the sawdust-based compost significantly affected the content of $\mathrm{NO}_{3}$, outperforming the treatment based on maize stover. The concentration of $\mathrm{Ca}^{++}$and $\mathrm{Mg}^{++}$in soils resulting from the applied composts was lower than in the treatment with inorganic fertilizer, but that of $\mathrm{Na}^{+}$was statistically higher than in the inorganic fertilizer treatment. This evidence suggests that the use of organic fertilizers, of either animal or plant origin, is a beneficial source of soil nutrients with high potential in sustainable agriculture.

Index words: macronutrients, organic fertilizer, soil fertility.

\section{RESUMEN}

El uso de desechos de ganado y residuos vegetales, como fuente de nutrientes y material orgánico para el suelo, puede representar una alternativa viable para evitar daños riesgosos para el agroecosistema, derivados del uso de fertilizantes químicos. El presente estudio fue conducido en 2013, en condiciones de invernadero en la FACIATEC-UACH, Chihuahua, México. Se evaluó la contribución al suelo de los macronutrientes $\mathrm{NO}_{3}^{-}$, $\mathrm{P}^{=}, \mathrm{K}^{+}, \mathrm{Ca}^{++}, \mathrm{Mg}^{++}$y $\mathrm{Na}^{+}$, a partir de cuatro compostas elaboradas de (a) estiércol de bovinos, (b) excremento de gallina, (c) aserrín y (d) esquilmo de maíz, los cuales fueron comparados con urea como fertilizante sintético y un control sin fertilizante. Se utilizó un diseño completamente aleatorizado y se realizó el análisis de varianza mediante el paquete estadístico SAS (Statistical Analysis System), versión 9.3.1; la comparación múltiple de medias se realizó mediante el procedimiento de Tukey $(\alpha=0.05)$. Los resultados sugieren que cinco de los tratamientos de compostas incrementaron la concentración de $\mathrm{NO}_{3}{ }^{-}$, en los cuales el estiércol de gallina superó significativamente al de bovinos en su aportación de los macronutrientes $\mathrm{NO}_{3}^{-}$ y $\mathrm{P}^{=}$; del mismo modo, las compostas elaboradas a partir de aserrín tuvieron un efecto significativo sobre el $\mathrm{NO}_{3}^{-}$y superaron a los que contenían esquilmos de maíz. La concentración de $\mathrm{Ca}^{++}$y $\mathrm{Mg}^{++}$en los suelos donde se aplicó la composta, fue menor en comparación con aquellos tratados con urea, aunque el contenido de $\mathrm{Na}^{+}$en los tratamientos de composta superó estadísticamente a la de aquellos tratados con fertilizantes inorgánicos. Esta evidencia sugiere que el uso de fertilizantes orgánicos, ya sea de origen animal 
o vegetal, es una fuente benéfica para los nutrientes del suelo con alto potencial en la agricultura sostenible.

Palabras clave: macronutrientes, fertilizante orgánico, fertilidad del suelo.

\section{INTRODUCTION}

The actual practice of agriculture with the use of chemical fertilizers is one of the main causes of today's environmental diseases. Although technological packages have produced high increases in crop yields, they have also had collateral effects such as losses of thousands of hectares of fertile land, soil degradation and increases of more virulent pathogens (Cruse, 2012). This technology is also responsible for eutrophication of bodies of water, increases in nitrate levels in ground and surface water, and increments of pesticide residues in water, soils and food (Tarigo et al., 2004) ${ }^{1}$.

Moreover, huge amounts of organic residues produced by agricultural activities have become environmental pollutants since they increase salinity levels, nitrate lixiviation rate into underground and drain water as well as phosphate concentration in surface water (Flotats and Sole, 2008). In addition, organic residues are associated with accumulation of lignin, aromatic oils and resins (Obied et al., 2005), and several pests, weeds and diseases have been disseminated (Baffi et al., 2007) and cases of toxicity in cultivated plants have increased (Zucconi et al., 1981). As a result, the use of organic residues has become increasingly important as an efficient way to recycle nutrients and stimulate plant growth as well as to incorporate nutrients to degraded soils (Cerrato et al., 2007). Hence, controlled degradation processes have been considered necessary to minimize environmental risks caused by organic residues as in the case of manure and urine (Lüebka and Lüebka, 2007) ${ }^{2}$.

Composting and biodegradation is an effective way to manage organic residues to obtain a healthier, safer, more economically profitable product while improving soil fertility (Bernal et al., 2008; Szabová et al., 2010). The factors involved in the composting process, such as aeration, initial $\mathrm{C} / \mathrm{N}$ relationship and moisture content, influence nutrient conservation, which are important in improving the potential of compost as organic fertilizer and its agronomical value (Guo et al., 2012). Application of organic fertilizers to agricultural soils is an important practice for increasing crop yield (Saldaña et al., 2014), and composts can improve physical, chemical and biological soil attributes (Soto and Melendez, 2003). The objective of this study was to evaluate the contribution of soil macronutrients by composts made from organic residues (plant and livestock wastes) as compared with inorganic fertilizers.

\section{MATERIALS AND METHODS}

\section{Experiment Location}

The experiment was conducted at the School of Agrotechnological Sciences (FACIATEC) of the Autonomous University of Chihuahua (UACH), Chihuahua, México, in a chapel-type greenhouse, $16 \mathrm{~m}$ wide $\times 45 \mathrm{~m}$ long, with galvanized iron structure and covered with fiberglass.

\section{Experimental Design}

The experimental design was completely randomized with ten fertilization treatments and five replications. The experimental unit was defined as a $6 \mathrm{~L}$ capacity pot. Treatments were set up with eight fertilizers based on four composts in two doses, a synthetic fertilizer (urea) and a control (no fertilizer). Composts were prepared from animal waste and plant residues and allowed to transform naturally for 25 weeks. For this purpose, we used hen manure $(\mathrm{H})$ and cow manure (C) as animal source; sawdust (S) and maize stover (M) were used as plant residues. The characteristics of the applied composts are shown in Table 1. Compost doses were 35 and $75 \mathrm{Mg} \mathrm{ha}^{-1}$, as recommended by Castellanos et al. (2000), to achieve an experimental soil with medium and high organic matter (OM) content, 2 and 3\% respectively, in this case based on an original content of $1.14 \%$ of $\mathrm{OM}$ and a sandy loam texture. The dose of urea (U) was $200 \mathrm{~kg} \mathrm{ha}^{-1}$. Treatments and doses are shown in Table 2. Composts and fertilizer were applied at the time of planting blue corn. Harvest took place 130 days after planting, when the soil sampling was performed.

\footnotetext{
${ }^{1}$ Tarigo, A., C. Repetto y D. Acosta. 2004. Evaluación agronómica de biofertilizantes en la producción de lechuga (Lactuca sativa) a campo. Tesis de Licenciatura Universidad de la Republica Facultad de Agronomía. Montevideo, Uruguay.

${ }^{2}$ Lüebka, U. y S. Lüebka. 2008. Materia orgánica como un recurso para la fertilidad. pp. 309-16. In: II Conferencia Internacional sobre eco-biología del suelo y el compost, 26-29 de noviembre 2008. SoilAce. Puerto de la Cruz, Tenerife, España.
} 
Table 1. Characteristics of four composts used as a source of organic fertilization.

\begin{tabular}{lccccccccccccc}
\hline Compost & $\mathrm{C}$ & $\mathrm{N}$ & $\mathrm{C} / \mathrm{N}$ & $\mathrm{P}$ & $\mathrm{K}$ & $\mathrm{Ca}$ & $\mathrm{Mg}$ & $\mathrm{Na}$ & $\mathrm{NO}_{3}$ & $\mathrm{Cu}$ & $\mathrm{Fe}$ & $\mathrm{Zn}$ & $\mathrm{Mn}$ \\
\hline
\end{tabular}

$\mathrm{HS}=$ hen manure and sawdust; $\mathrm{CS}=$ cow manure and sawdust; $\mathrm{HM}=$ hen manure and maize stover; $\mathrm{CM}=$ cow manure and maize stover.

\section{Response Variables}

Soil samples were dried at room temperature from 34 to $40{ }^{\circ} \mathrm{C}$. The variables evaluated in soil were concentration of $\mathrm{NO}_{3}^{-}$by the Brucine method and UV-visible spectrophotometry (HACH DR 5000-UVvisible) (Uvalle-Bueno, 1993) and the major elements $\mathrm{K}^{+}, \mathrm{Ca}^{++}, \mathrm{Mg}^{++}$and $\mathrm{Na}^{+}$, through ammonium acetate and atomic absorption spectrophotometry (Perkin Elmer Analyst 100, New Jersey, US), $\mathrm{P}^{=}$with the ammonium molybdenum vanadate method and UV-visible spectrophotometry analysis (HACH DR 5000-UVvisible) (Nogales et al., 2005).

\section{Statistical Analysis and Hypothesis Testing}

The first stage of the ANOVA was applied in a Completely Randomized Design (CRD). Since $\mathrm{H}_{\mathrm{o}}$ was rejected, we proceeded to perform the hypothesis test for each of the contrasts and response variables, using 1 degree of freedom in each $\left(\mathrm{H}_{\mathrm{o}}: \sigma_{\mathrm{t}}^{2} / \sigma_{\mathrm{e}}^{2}=\right.$ 1; $\left.H_{a}: \sigma_{t}^{2} \sigma_{e}^{2}>1\right)$. Nine hypotheses were tested, corresponding to each contrast $\left(\lambda_{i}\right)$, as follows: $\mathrm{H}_{\mathrm{o}}: \lambda_{\mathrm{i}}=0 ; \mathrm{H}_{\mathrm{a}}: \lambda_{\mathrm{i}} \neq 0$.

\section{Orthogonal Contrasts}

A set of orthogonal contrasts was defined a priori under the requirements of orthogonality (independence) explained as follows: (1) all treatments vs control, (2) organic vs inorganic fertilizers, (3) composting based on hen manure $(\mathrm{H})$ vs fertilizers based on cow manure (C), (4) compost based on sawdust (S) vs compost based on maize stover (M), (5) fertilization with $35 \mathrm{Mg} \mathrm{ha}^{-1}$ of hen manure + sawdust compost (HS) vs $75 \mathrm{Mg} \mathrm{ha}^{-1}$ of the same mixture; (6) fertilization with $35 \mathrm{Mg} \mathrm{ha}^{-1}$ of hen manure + maize stover (HM) compost vs $75 \mathrm{Mg} \mathrm{ha}^{-1}$ of the same mixture; (7) fertilization with $35 \mathrm{Mg} \mathrm{ha}^{-1}$ of cow manure + sawdust compost (CS) vs $75 \mathrm{Mg} \mathrm{ha}^{-1}$ of the same mixture; (8) fertilization with $35 \mathrm{Mg} \mathrm{ha}^{-1}$ of cow manure + maize stover compost $(\mathrm{CM})$ vs $75 \mathrm{Mg} \mathrm{ha}^{-1}$ of the same mixture, and (9) interaction manure*crop residues. Statistical analysis was performed using PROC GLM of SAS version 9.1.3.

\section{RESULTS AND DISCUSSION}

The analysis of soil macronutrients revealed significant changes in their concentrations in the different treatments (Table 3). Results of nine independent comparisons selected a priori reveal that only orthogonal contrast of all (all types of fertilizers) vs control (no fertilizer) significantly affected the concentration of six nutrients, while the HS-35 Mg ha ${ }^{-1}$ vs HS-75 Mg ha ${ }^{-1}$ contrast had no effect on the levels of the macronutrients.

These findings agree with those observed by other researchers. Bernal et al. (2008), for example, mentioned that bulking agents such as cereal straw

Table 2. Treatments with organic and inorganic fertilization.

\begin{tabular}{lllllllllll}
\hline Treatment & $\mathrm{T}_{1}$ & $\mathrm{~T}_{2}$ & $\mathrm{~T}_{3}$ & $\mathrm{~T}_{4}$ & $\mathrm{~T}_{5}$ & $\mathrm{~T}_{6}$ & $\mathrm{~T}_{7}$ & $\mathrm{~T}_{8}$ & $\mathrm{~T}_{9}$ & $\mathrm{~T}_{10}$ \\
\hline Ky & HS-35 & HS-75 & $\mathrm{CS}-35$ & $\mathrm{CS}-75$ & HM-35 & HM-75 & CM-35 & CM-75 & U-200 & C \\
Dose $\left(\mathrm{Mg} \mathrm{ha}^{-1}\right)$ & 35 & 75 & 35 & 75 & 35 & 75 & 35 & 75 & 0,2 & 0 \\
\hline
\end{tabular}

$\mathrm{HS}=$ hen manure and sawdust; $\mathrm{CS}=$ cow manure and sawdust; $\mathrm{HM}=$ hen manure and maize stover; $\mathrm{CM}=$ cow manure and maize stover. 
Table 3. Mean squares and statistical significance of six macronutrients associated with application of different fertilizers (organic and inorganic).

\begin{tabular}{|c|c|c|c|c|c|c|c|}
\hline \multirow{2}{*}{ Source of variation } & \multirow{2}{*}{$\mathrm{df}$} & \multicolumn{6}{|c|}{ Soil macronutrients } \\
\hline & & $\mathrm{NO}_{3}^{-}$ & $\mathrm{P}^{=}$ & $\mathrm{K}^{+}$ & $\mathrm{Ca}^{++}$ & $\mathrm{Mg}^{++}$ & $\mathrm{Na}^{+}$ \\
\hline Treatments & 9 & $2.46^{*}$ & $6848^{*}$ & $148555^{*}$ & 10711398* & $6576^{*}$ & $0.0421 *$ \\
\hline All vs control & 1 & $10.15^{*}$ & $12792 *$ & $611433^{*}$ & $24041333 *$ & $10396^{*}$ & $0.0645^{*}$ \\
\hline Org vs inorg & 1 & $5.56^{*}$ & $13197 *$ & 527085 & $27569835^{*}$ & $8146^{*}$ & 0.0538 \\
\hline Hen manure vs cow manure & 1 & $0.412 *$ & $28585^{*}$ & 140 & $6460140 *$ & 316 & 0.0109 \\
\hline Sawdust vs maize stover & 1 & $0.533^{*}$ & 1296 & 6250 & 4709390* & 472 & 0.0194 \\
\hline HS-35 vs HS-75 & 1 & 0.004 & 1638 & 1890 & 4000 & 62 & 0.0012 \\
\hline HM-35 vs HM-75 & 1 & 0.007 & $3546^{*}$ & 74390 & 5062 & 765 & $0.0774 *$ \\
\hline CS-35 vS CS-75 & 1 & 0 & 555 & 1562 & 6250 & $3062 *$ & $0.0980 *$ \\
\hline CM-35 vs CM-75 & 1 & $3.624 *$ & 1 & 4000 & $25840562 *$ & $25000 *$ & 0.0436 \\
\hline Interaction $\mathrm{M} * \mathrm{~V}$ & 1 & $1.857^{*}$ & 22 & 110250 & $7766015^{*}$ & $10972 *$ & 0.0109 \\
\hline Error & 40 & 0.057 & 787 & 29870 & 78750 & 440 & 0.0132 \\
\hline Mean & & 2.61 & 66.2 & 1109 & 2134.75 & 209.2 & 7.18 \\
\hline $\mathrm{CV}(\%)$ & & 9.18 & 42.4 & 15.58 & 13.14 & 10.03 & 1.6 \\
\hline $\mathrm{R}=\mathrm{r}^{2}$ & & 0.906 & 0.662 & 0.662 & 0.968 & 0.77 & 0.42 \\
\hline
\end{tabular}

and sawdust have high organic-C contents and high $\mathrm{C} / \mathrm{N}$ ratios (above 50). Moreover, mature composts produced from cattle and poultry manure mixed with agricultural and forestry by-products provide beneficial effects on soil physical, chemical and biological properties as well as nutrient content. It has also been mentioned that bovine manure, being a rich source of carbon and nitrogen, increased microbial activity, and consequently led to increased availability of nutrients for the plant (Lincoff, 1981).

The contrast all vs control, significantly affected all nutrients. Some contrasts (CS-35 vs CS-75; HM35 vs HM-75), however, had significant effect on at least one of the nutrients. The concentrations of $\mathrm{NO}_{3}^{-}$ and $\mathrm{Ca}^{++}$were affected significantly by six of the nine contrasts, while the level of $\mathrm{K}^{+}$responded only to the contrast all vs control, probably because most of the soils in temperate zones in Mexico are rich in this macronutrient, the reason that potassium fertilizers are usually not applied or the required doses are low. The interaction $\mathrm{M}^{*} \mathrm{~V}$ had a significant effect on macronutrients $\mathrm{NO}_{3}^{-}, \mathrm{Ca}^{++}$and $\mathrm{Mg}^{++}$.

The coefficients of variation (CV) observed were 1.6 and $42.4 \%$ for $\mathrm{Na}^{+}$and $\mathrm{P}^{=}$, respectively. This suggests that the concentration of the first was relatively constant. The second, on the contrary, was more affected by the application of organic and inorganic fertilizers, particularly by the composts prepared in this study.

The highest coefficient of determination $\left(\mathrm{R}^{2}\right)$ was estimated for $\mathrm{Ca}^{++}$(0.968). At the other extreme, the macronutrient $\mathrm{Na}^{+}$exhibited the lowest (0.42). For $\mathrm{Ca}^{++}$, the percentage of the total variation $(96.8 \%)$ explained by the experimental design was close to $100 \%$, while the value of $42 \%$ for $\mathrm{Na}^{+}$, indicated that the error component (random causes) was proportionally higher than that, due to the effect of the treatments. The coefficients of determination of the rest of macronutrients ranged between 0.662 and 0.906 . All of these values were higher than 0.5 ; that is, more than $50 \%$ of the variation was explained by the statistical model used in the study.

By comparing the concentrations of nutrients $\mathrm{NO}_{3}, \mathrm{P}^{=}$and $\mathrm{K}^{+}$(Table 4), it was found that the control had the lowest means $75.4,5$ and $777.5 \mathrm{mg} \mathrm{kg}^{-1}$, respectively, while the highest means, 268.2, 33.8 and $1267.5 \mathrm{mg} \mathrm{kg}^{-1}$, were recorded for treatments CS-75, HS-75 and CM-75, respectively, in all three cases with the highest dose of compost $\left(75 \mathrm{Mg} \mathrm{ha}^{-1}\right)$. 
Table 4. Means comparison and significant groups of six soil macronutrients $\left(\mathrm{mg} \mathrm{kg}^{-1}\right)$ from organic and inorganic sources.

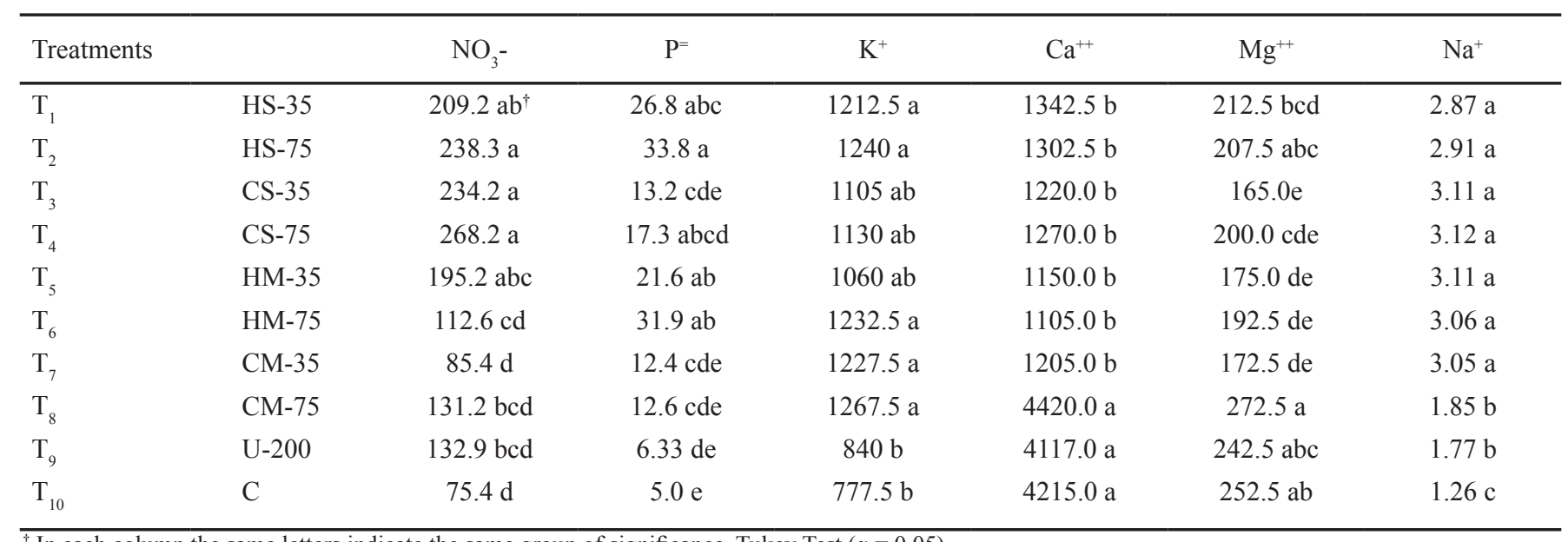

${ }^{\dagger}$ In each column the same letters indicate the same group of significance. Tukey Test $(\alpha=0.05)$.

For nutrients $\mathrm{Ca}^{++}$and $\mathrm{Mg}^{++}$, the means of the control (4215 and $252 \mathrm{mg} \mathrm{kg}^{-1}$ ) were among the top three, although they were statistically equal (Table 4), while treatments CM-75 and U-200 were, respectively, first and second with the means 4420 and $4117 \mathrm{mg} \mathrm{kg}^{-1}$ for the element $\mathrm{Ca}^{++} ; 272.5$ and $245.5 \mathrm{mg} \mathrm{kg}^{-1}$ for the nutrient $\mathrm{Mg}^{++}$. These results clearly demonstrate a substantial improvement in the concentration of the above mentioned nutrients, in response to the application of compost obtained by mixing manure and plant residues, as has been pointed out by several researchers (Fox et al., 1989; Magdoff, 1991; Blackmer, 1992).

The comparison of means test of the control (Table 4) revealed the presence of at least two significance groups for $\mathrm{K}^{+}$and $\mathrm{Ca}^{++}$and up to five groups for $\mathrm{P}^{=}$ and $\mathrm{Mg}^{++}$averages. As mentioned above, the control group had the lowest average for nutrients $\mathrm{NO}_{3}^{-}, \mathrm{P}^{=}, \mathrm{K}^{+}$ and $\mathrm{Na}^{+}$; however, it can be seen that in five of the six nutrients, the control was statistically equal to at least one other treatment, as with the element $\mathrm{K}^{+}, 777.5$ and $840 \mathrm{mg} \mathrm{kg}^{-1}$, for the control and inorganic fertilization, respectively. When analyzing the $\mathrm{Na}^{+}$element, the presence of three groups of significance is remarkable: group a, formed by treatments $T_{1}$ to $T_{7}$ (means varied from 2.87 to $3.12 \mathrm{mg} \mathrm{kg}^{-1}$ ), group $\mathrm{b}$, formed by treatments $\mathrm{T}_{8}$ and $\mathrm{T}_{9}\left(1.85\right.$ and $\left.1.77 \mathrm{mg} \mathrm{kg}^{-1}\right)$; group c, the control $\left(\mathrm{T}_{10}\right)$, with the lowest mean $\left(1.26 \mathrm{mg} \mathrm{kg}^{-1}\right)$.
The responses observed in the present study agreed with other studies carried out by several researchers, who reported significant increases in the concentration of nutrients. For instance, López et al. (2001) reported values of $\mathrm{N}$ of 2.18 and $1.80 \%$, when organic fertilizer made from hen manure and cow manure were applied. In a critical review, Bernal et al. (2008) discussed the important role of bulking agents such as cereal straw and wood by-products (sawdust), which have high organic- $\mathrm{C}$ contents and high $\mathrm{C} / \mathrm{N}$ ratios, on maturity index of compost produced when they are mixed with cattle manure and poultry manure. This also supports the idea of the effect of the interaction manure $\times$ plant residues on soil mineral content. These results have also been observed in other studies, where responses to compost application were evaluated in the stages of growth and fruit development (Ortega et al., 2010). Similar results have been reported by Apolinar (2006), who applied a mixture of sawdust-compost to a soil cultivated with tomato, demonstrating the benefits of sawdust as a bulking agent used to produce composts. In addition, this researcher reported improvement in physical-chemical properties of the soil fertilized with compost mixed with sawdust.

Millaleo et al. (2006) reported increases in the concentration and availability of $\mathrm{P}^{=}$when high doses of organic fertilizers made from livestock manure and crop residues were applied. The same authors observed

\footnotetext{
${ }^{3}$ Apolinar, S. 2006. Índices fisiotécnicos en la productividad de seis híbridos de tomate (Lycopersicum esculetum Mill) en cultivos sin suelo en invernadero. Tesis de Licenciatura. Instituto Tecnológico del Valle de Oaxaca, Ex Hacienda de Nazareno, Xoxocotlan, Oaxaca México. 107 p.
} 
a significant increase in crop foliage biomass and availability of several nutrients. Other authors (Laboski and Lamb, 2003) observed an increase in the availability of $\mathrm{P}^{=}$when livestock manure was applied because its concentration in the organic amendment can be equal to or greater than. Another factor that may explain the results reported in this research is the production of organic acids during microbial degradation of organic fertilizer applied to soil, as they can increase nutrient availability to plants (Gale et al., 2000). Beneficial effects on soil-plant system properties, such as improved physical characteristics, increased nutrient contents, soil fertility, higher biological and enzymatic activity, have been observed after applying composts (Roca et al., 2008).

Average $\mathrm{P}^{=}$content in hen manure-sawdust mixture composts was HS-35 (26.8 $\left.\mathrm{mg} \mathrm{kg}^{-1}\right)$ and HS-75 (33.8 $\mathrm{mg} \mathrm{kg}^{-1}$ ); in cow manure-sawdust composts it was CS-35 (13.2 $\left.\mathrm{mg} \mathrm{kg}^{-1}\right)$ and CS-75 (17.3 $\left.\mathrm{mg} \mathrm{kg}^{-1}\right)$. It was observed that in the first group the means were almost double the value of the second group (Table 4). Similar studies (Jiménez et al., 2004), where cattle manure was used without mixing with sawdust, reported concentrations of $\mathrm{P}^{=}$between $16.54 \mathrm{mg} \mathrm{kg} \mathrm{kg}^{-1}$ and $38.10 \mathrm{mg} \mathrm{kg}^{-1}$, far below the values observed here. This suggests a positive significant effect of the interaction manure x sawdust. Pérez et al. (2008) recorded a concentration of $247.45 \mathrm{Mg} \mathrm{ha}{ }^{-1} \mathrm{P}^{=}$in response to compost made from mixtures of hen droppings and cow manure. These values exceed the results presented in our paper by nearly $60 \%$.

For $\mathrm{K}^{+}$, averages from $777.5 \mathrm{mg} \mathrm{kg}^{-1}$ (control) to $1267.5 \mathrm{mg} \mathrm{kg}^{-1}$ (BE-75) were reported in our work. However, eight of the 10 treatments compared were part of the group of significance, which includes the highest average (Table 4). Arrieche $(2008)^{4}$ reported a $\mathrm{K}^{+}$concentration average of $278.8 \mathrm{mg} \mathrm{kg}^{-1}$, contribution achieved with composts were made with chicken manure and cachaza. The composts were applied to improve soil properties; however, these values were lower than those reported in our study.

Two groups of significance for the nutrient $\mathrm{Ca}^{++}$ were observed, fluctuating between the treatment means of 1105 and $4420 \mathrm{mg} \mathrm{kg}^{-1}$ (Table 4). Other researchers (Olivares et al., 2012) have reported values close to $4800 \mathrm{mg} \mathrm{kg}^{-1}$ in soils fertilized with compost made from cattle manure; this is greater than the average of the treatments compared in our study. Similarly, the results of this study agree with those reported by Carmo et al. (2016), who observed that only chicken and quail manures, substrate and compost, had a significant effect on $\mathrm{Ca}^{++}$concentration. Also, Olivares et al. (2012), using cattle manure mixed with sawdust, reported an average contribution to soil of $\mathrm{Ca}^{++}$of $4500 \mathrm{mg} \mathrm{kg}^{-1}$, similar to those of some of the treatments analyzed in our work.

The average concentrations of $\mathrm{Mg}^{++}$in treatments varied between 165 and $252 \mathrm{mg} \mathrm{kg}^{-1}$. These results differ from Olivares et al., 2012, who reported an average of $5200 \mathrm{mg} \mathrm{kg}^{-1}$ when manure-based compost and sawdust were applied. This value was higher than the best treatment of our study. Cortés et al. (2008) reported values of 604 to $797 \mathrm{mg} \mathrm{kg}^{-1}$ with fertilizers based on cattle manure; these values were also higher than the results presented in Table 4. Arrieche and Ramírez (1997), Lora (1998) and Brito et al. (2004) noted that values between 100 and $150 \mathrm{mg} \mathrm{kg}^{-1} \mathrm{Mg}^{++}$ are suitable for a sandy loam soil, such as that used in this study; thus, the values obtained in this study can be considered acceptable.

The average concentration of $\mathrm{Na}^{+}$varied from 1.26 to $3.12 \mathrm{mg} \mathrm{kg}^{-1}$ (Table 4), values that differ from those observed in other studies (Olivares et al., 2012), where a combination of manure and sawdust was applied, yielding an average of $900 \mathrm{mg} \mathrm{kg}^{-1}$, much higher than the value found in our study. Canet et al. (1998) reported lower concentrations than those observed here $\left(0.22 \mathrm{mg} \mathrm{kg}^{-1}\right)$ when they applied ovine manure. It is important to avoid high values of $\mathrm{Na}^{+}$because the osmotic pressure generated in the groundwater interferes with the growth of most crops.

\section{CONCLUSIONS}

Five treatments of compost applied to soils significantly increased concentrations of $\mathrm{NO}_{3}^{-}$ compared with inorganic fertilization and the control. Compost produced from hen manure provided a more consistent effect on the concentration of $\mathrm{NO}_{3}{ }^{-}$and $\mathrm{P}^{=}$in soil, relative to cow manure. Sawdust-based composts had a greater effect on the content of $\mathrm{NO}_{3}^{-}$, compared with maize stover-based compost. The average

\footnotetext{
${ }^{4}$ Arrieche, L. I. 2008. Efecto de la fertilización orgánica y química en suelos degradados cultivados con Maíz (Zea mays L.) en el estado Yaracuy, Venezuela. Tesis Doctoral. Universidad de Valladolid. Departamento de Agrociencias Forestales. p 71.
} 
concentration of $\mathrm{Ca}^{++}$and $\mathrm{Mg}^{++}$in soils with organic fertilizers was lower than those caused by inorganic fertilization. The average concentration of $\mathrm{Na}$ in soils with organic fertilizers was higher than that observed with inorganic fertilization.

\section{ACKNOWLEDGEMENT}

Authors acknowledge Mrs. Nancy Karina Venegas Hernández for reviewing the English of this manuscript.

\section{REFERENCES}

Arrieche, E. and R. Ramirez.1997. Soil test for available zinc in acid soils of Venezuela. Comm. Soil Sci. Plant Anal. 28: 1471-1480.

Baffi, C., M. T. Dell'Abate, A. Nassisi, S. Silva, A. Benedetti, P. L. Genevini, and F. Adani. 2007. Determination of biological stability in compost: A comparison of methodologies. Soil Biol. Biochem. 39: 1284-1293.

Bernal, M. P., J. A. Alburquerque, and R. Moral. 2009. Composting of animal manures and chemical criteria for compost maturity assessment. A review. Bioresour. Technol. 100: 5444-5453.

Blackmer, A. M. 1992. Nitrogen needs for corn in a sustainable agriculture. pp. 159-172. In: D. Wilkinson (ed.). Report of annual corn and sorghum research conference. 44th Corn and sorghum research conference. American Seed Trade Association. Chicago, IL, USA.

Brito, G., I. Arrieche, E. Bisbal, N. Alfonzo, M. Navas, N. Gómez y P. Yanes. 2004. Manual de métodos y procedimientos de referencia (Análisis de suelo para diagnóstico de fertilidad). INIA. Venezuela.

Canet, R., F. Pomares, M. Estela y F. Tarazona. 1998. Efecto de diferentes enmiendas orgánicas en las propiedades del suelo de un huerto de cítricos. Agrochimica 42: 41-42.

Carmo, D. L., L. B. Lima, and C. A. Silva. 2016. Soil fertility and electrical conductivity affected by organic waste rates and nutrient inputs. Rev. Bras. Ciênc. Solo 40: e0150152. doi: 10.1590/18069657rbcs20150152.

Castellanos, J. Z., J. X. Uvalle-Bueno y A. Aguilar-Santelises. 2000. Manual de Interpretación de análisis de suelos, aguas agrícolas, plantas y ECP. INIFAP-Gto. Chapingo Edo. de México, México.

Cerrato, M. E., H. A. Leblanc y C. Kameko. 2007. Potencial de mineralización de nitrógeno de Bokashi, compost y lombricompost producidos en la Universidad Earth. Tierra Trop. 161-175.

Cortés Jiménez, J. M. 2008. Resultados con el uso de estiércoles en trigo Valle del Yaqui, Sonora. pp. 37-61. In: J. M. Cortés Jiménez, C. Valenzuela S. Y H. R. Uribe M. (eds.). Seminario sobre uso de abonos orgánicos en la agricultura. INIFAP. Cd. Obregón Sonora, México.

Cruse, R. 2012. Agriculture: Is climate change a serious issue? Agrociencia 16: 9-19.
Flotats R., J. y F. Solé M. 2008. 2. Situación actual en el tratamiento de los residuos orgánicos: Aspectos científicos, económicos y legislativos. pp. 44-73. In: J. Moreno C. y R. Moral H. (eds.). Compostaje. Mundi-Prensa. Madrid, España,

Fox, R. H., G. W. Roth, K. V. Iversen, and W. P. Piekielek. 1989. Soil and tissue nitrate test compared for predicting soil nitrogen availability to corn. Agron. J. 81: 971-974.

Gale, P. M., M. D. Mullen, C. Cieslik, D. D. Tyler, B. N. Deuk, M. Kirchner, and J. McClure. 2000. Phosphorus distribution and availability in response to dairy manure applications. Commun. Soil Sci. Plant Anal. 31: 553-565.

Guo, R., G. Li, T. Jiang, F. Schuchardt, T. Chen, Y. Zhao, and Y. Shen. 2012. Effect of aeration rate, $\mathrm{C} / \mathrm{N}$ ratio and moisture content on the stability and maturity of compost. Bioresour. Technol. 112: 171-178.

Jiménez, L., M. Larreal, y N. Noguera. 2004. Efectos del estiércol bovino sobre algunas propiedades químicas de un Ultisol degradado en el área de la Machiques Colón, estado Zulia. Rev. Fac. Agron. (Luz) 21: 311-321.

Laboski, C. A. M. and J. A. Lamb. 2003. Changes in soil test phosphorus concentration after application of manure or fertilizer. Soil Sci. Soc. Am. J. 67: 544-554.

Lincoff, G. H. 1981. The Audubon society field guide to North American mushrooms. A. A. Knopf, Inc. Nueva York, NY, USA.

López M., J. D., A. Díaz E., E. Martínez R. y R. D. Valdez C. 2001. Abonos orgánicos y su efecto en propiedades físicas y químicas del suelo y rendimiento en maíz. Terra 19: 293-299.

Lora S., R. 1998. Análisis de suelos y material vegetal para micronutrimentos. pp. 47-56. In: F. Silva M. (ed.). Curso actualidad y futuro de los micronutrimentos en la agricultura. Bogotá D.C., Colombia. ISBN: 958-96518-0-1.

Magdoff, F. 1991. Understanding the Magdoff Pre-sidedress nitrate test for corn. J. Prod. Agric. 4: 297-305.

Millaleo M., R., C. Montecinos U., R. Rubio H., A. Contreras N. y F. Borie B. 2006. Efecto de los propágulos micorrícicos arbusculares en un suelo volcánico del centro sur de Chile. R. C. Suelo Nutr. Veg. 6: 26-39.

Nogales, R., C. Cifuentes, and E. Benítez. 2005. Vermicomposting of winery wastes: A laboratory study. J. Environ. Sci. Health B 1234: 659-573.

Obied, H. K., M. S. Allen, D. R. Bedgood, P. D. Prenzler, K. Robards, and R. Stockmann. 2005. Bioactivity and analysis of biophenols recovered from olive mill waste. J. Agric. Food Chem. 53: 823-837.

Olivares C., M. A., A. Hernández R., C. Vences C., J. L. Jáquez B. y D. Ojeda B. 2012. Lombricomposta y composta de estíércol de ganado vacuno lechero como fertilizantes y mejoradores de suelo. Univ. Cienc. 28: 27-37.

Ortega M., L. D., J. Sánchez O., J. Ocampo M., E. Sandoval C., B. A. Salcido C., y F. Manzo R. 2010. Efecto de diferentes sustratos en crecimiento y rendimiento de tomate (Lycopersicum esculentum Mill) bajo condiciones de invernadero. Ra Ximhai 6: 339-346.

Pérez, A., C. Céspedes y P. Núñez. 2008. Caracterización físicaquímica y biológica de enmiendas orgánicas aplicadas en la producción de cultivos en República. Soil Sci. Plant Nutr. Veg. 8: 10-29. 
Roca-Pérez, L., C. Martínez, P. Marcilla, and R. Boluda. 2009. Composting rice straw with sewage sludge and compost effects on the soil-plant system. Chemosphere 75: 781-787.

Saldaña Hernández, M. I., R. Gómez A., M. C. Rivera Cruz, J. D. Álvarez Solís, C. F. Ortiz y J. M. Pat Fernández. 2014. Efecto de abonos orgánicos en la dinámica microbiológica del suelo y producción de Alpinia purpurata (Vieill) K. Schum. Interciencia 39: 809-815.

Soto, G. y G. Meléndez. 2003. Cómo medir la calidad de los abonos orgánicos. Hoja técnica no. 48. Manejo Int. Plagas Agroecol. 72: 91-97
Szabová, E., P. Juriš e I. Papajová. 2010. Sanitation composting process in different seasons. Ascaris suum as model. Waste Manage. 30: 426-432.

Uvalle-Bueno, X. 1993. Laboratorio de suelos del Centro de Investigaciones Regionales del Noroeste (CIRNO-INIFAP). Cd. Obregón, Sonora, México.

Zucconi, F., A. Pera, M. Forte, and M. de Bertoldi. 1981. Evaluating toxicity of inmature compost. BioCycle 22: 54-57. 